Article

\title{
Base-Promoted Annulation of Amidoximes with Alkynes: Simple Access to 2,4-Disubstituted Imidazoles
}

Hina Mehmood, Muhammad Asif Iqbal, Le Lu® and Ruimao Hua *

Key Laboratory of Organic Optoelectronics \& Molecular Engineering of Ministry of Education, Department of Chemistry, Tsinghua University, Beijing 100084, China; hinamehmood123@gmail.com (H.M.);

ykb15@mails.tsinghua.edu.cn (M.A.I.); lul18@mails.tsinghua.edu.cn (L.L.)

* Correspondence: ruimao@mail.tsinghua.edu.cn; Tel.: +86-10-6279-2596

Academic Editor: Andrea Penoni

Received: 30 June 2020; Accepted: 6 August 2020; Published: 9 August 2020

\begin{abstract}
An efficient construction of imidazole ring by a $\mathrm{Cs}_{2} \mathrm{CO}_{3}$-promoted annulation of amidoximes with terminal alkynes in DMSO has been developed. This protocol provides a simple synthetic route with high atom-utilization for the synthesis of 2,4-disubstituted imidazoles in good yields under transition-metal-free and ligand-free conditions. Internal alkynes can also undergo the annulation to give 2,4,5-trisubstituted imidazoles.
\end{abstract}

Keywords: base-promoted; annulation; amidoximes; alkynes; 2,4-disubstituted imidazoles

\section{Introduction}

Imidazole ring is the important class of nitrogen-heterocyclic structural motif that has been found in several commercial drugs, such as olmesartan [1-4] and losartan [5-7], for the treatment of hypertension, and ondansetron [8-11] for reducing nausea and emesis, which have become the best-selling five-membered ring heterocyclic pharmaceuticals [12] (Figure 1). Molecules having this nitrogen-heterocyclic structure often exhibit important and interesting physiological and biological activities [13-15]. In addition, imidazoles have been also used as ligands in organometallic complexes [16,17]. Therefore, there has been increasing interest in the developments of efficient methodologies for the construction of imidazole ring [18-20].
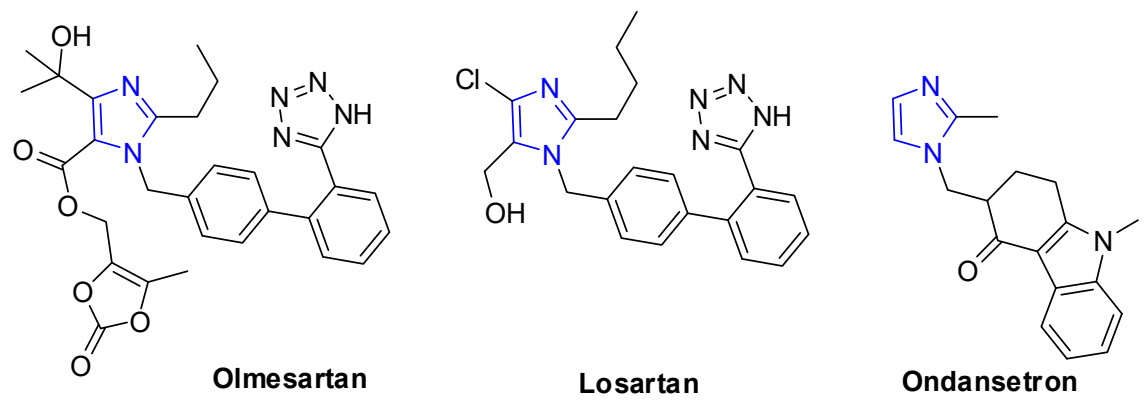

Figure 1. Examples of commercial drugs with imidazole skeleton.

Among them, the construction of imidazole starting from alkyne as one of the reactants has been well developed. As depicted in Scheme 1, one of the classic approaches to synthesize 1,2,4,5-tetrasubstituted or 2,4,5-trisubstituted imidazoles is the three-component cyclization of $\alpha$-diketone, aldehyde, and amine or ammonia sources catalyzed by transition metal complexes or under 
acidic conditions (Equation (1)). Recently, this protocol has been evolved using internal alkynes as starting materials via generating 1,2-diketones in situ by oxidation reaction [21-24]. On the other hand, the formal [3+2] annulation of substituted amidines with alkyne forming imidazole ring usually shows high atom-utilization, and two representative procedures are concluded in Scheme 1. One of the known procedures is the annulation of amidines with terminal alkynes catalyzed by $\mathrm{CuCl}_{2} \cdot 2 \mathrm{H}_{2} \mathrm{O}$ in pyridine in the presence of $\mathrm{Na}_{2} \mathrm{CO}_{3}$ under atmospheric oxygen to afford 1,2,4-trisubstituted imidazoles in modest to good yields (Equation (2)) [25]. The other involves the cyclocondensation of amidine hydrochlorides with bromoacetylenes promoted by $\mathrm{K}_{2} \mathrm{CO}_{3}$ under air in the presence of 2,2'-bipyridine and water affording various 2,5-disubstituted imidazoles in good yields (Equation (3)) [26]. It is readily apparent to find that, in addition to the requirement of $\mathrm{CuCl}_{2} \cdot 2 \mathrm{H}_{2} \mathrm{O}$ and/or ligand (pyridine and 2,2'-bipyridine), in both cases, inorganic bases were used as the additives, indicating that base is the key promoter to realize the formation of imidazoles. Therefore, in continuation of our interest in developing alkyne annulation in the synthesis of nitrogen-heterocyclic compounds [27-30] and base/DMSO-promoted C-N bond formation [31-34], we decided to explore the possibility of constructing an imidazole ring with the use of inorganic bases as the promoters, without the use of ligands under transition-metal-free conditions. In this paper, we would like to report a new, simple and efficient procedure to afford a variety of 2,4-disubstituted imidazoles starting with amidoximes and terminal alkynes in the presence of $\mathrm{Cs}_{2} \mathrm{CO}_{3}$ in DMSO (Equation (4)) [35].

Previous works:

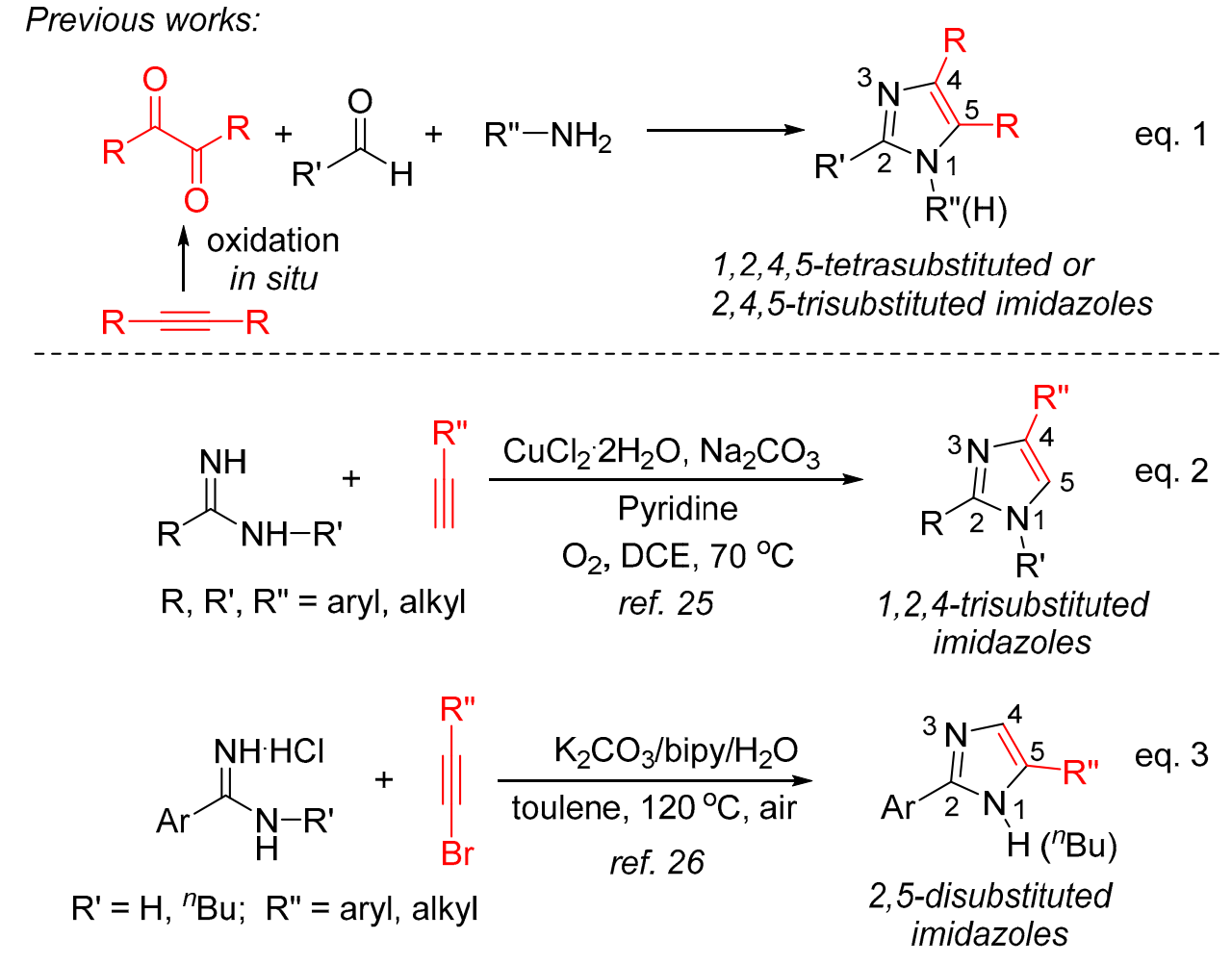

This work:

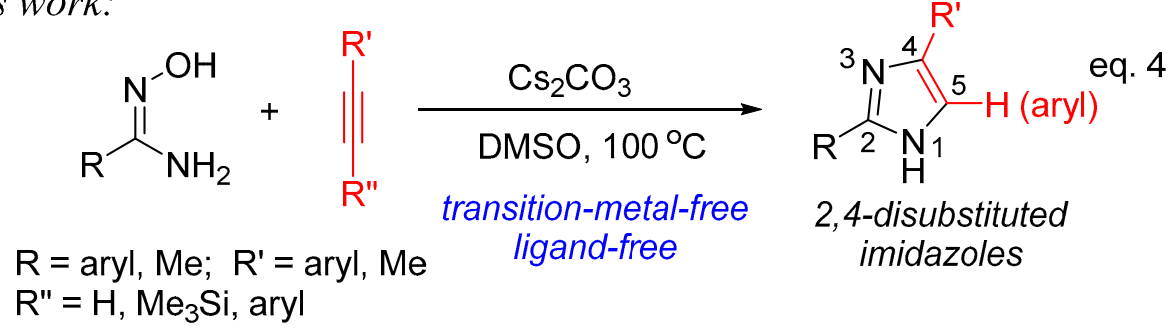

Scheme 1. Synthesis of diverse position-substituted imidazoles from alkynes. 


\section{Results and Discussion}

We firstly examined the reaction of benzamidoxime ( $N^{\prime}$-hydroxybenzimidamide) (1a) with phenyl acetylene (2a, 2.0 equivalent) in the presence of $\mathrm{Na}_{2} \mathrm{CO}_{3}$ (4.0 equivalent) in DMSO at $100{ }^{\circ} \mathrm{C}$ for $24 \mathrm{~h}$; fortunately, 2,4-diphenylimidazole (3aa) could be isolated from the reaction mixture in a $10 \%$ yield (Table 1, entry 1). The structure of 3aa was characterized by its ${ }^{1} \mathrm{H}$ - and ${ }^{13} \mathrm{C}-\mathrm{NMR}$ spectral data, which are the same as the reported ones. In addition, 3aa was recrystallized in a mixed solvents of petroleum/EtOAc/EtOH as white crystals, its X-ray diffraction studies confirm the structure unambiguously [36].

Several other inorganic bases, such as $\mathrm{K}_{2} \mathrm{CO}_{3}, \mathrm{KOH}, \mathrm{KO}{ }^{t} \mathrm{Bu}$ and $\mathrm{Cs}_{2} \mathrm{CO}_{3}$, were then examined, and 3aa could be obtained in a 34 75\% yield (Table 1, entries $2-5$ ). These results indicate that, in DMSO, $\mathrm{Cs}_{2} \mathrm{CO}_{3}$ is the best base for the present transformation, thus, the influence of other solvents and the amounts of $1 \mathrm{a}$ and $\mathrm{Cs}_{2} \mathrm{CO}_{3}$ were investigated. As shown in entries 6-8, when THF, 1,4-dioxane and DMF were used as solvents to replace DMSO, the yields of 3aa were decreased significantly. In addition, decreasing amounts of $2 \mathrm{a}$ (from 2.0 equivalent to 1.5 equivalent or 1.0 equivalent) resulted in the considerable decrease of yields (Table 1, entries 9-10). Although the use of 2.5. of $\mathrm{Cs}_{2} \mathrm{CO}_{3}$ also gave results similar to those in entry 5 (Table 1, entry 11 vs. entry 5), the yields of 3aa were reduced when 1.0 equivalent or 0.5 . of $\mathrm{Cs}_{2} \mathrm{CO}_{3}$ were used (Table 1 , entries 12-13). In addition, as discussed above, the base is the key promoter to promote the formation of imidazoles, the absence of $\mathrm{Cs}_{2} \mathrm{CO}_{3}$ led to no 3aa formation at all (Table 1, entry 14).

Table 1. Optimizing reaction conditions for imidazole synthesis ${ }^{a}$.

\begin{tabular}{|c|c|c|c|c|}
\hline Entry & 2a (equiv) & Base(equiv) & Solvent & Yield $(\%) b$ \\
\hline 1 & 2.0 & $\mathrm{Na} 2 \mathrm{CO} 3(4)$ & DMSO & 10 \\
\hline 2 & 2.0 & $\mathrm{~K} 2 \mathrm{CO} 3(4)$ & DMSO & 34 \\
\hline 3 & 2.0 & $\mathrm{KOH}(4)$ & DMSO & 53 \\
\hline 4 & 2.0 & $\mathrm{KO}^{t} \mathrm{Bu}(4)$ & DMSO & 41 \\
\hline 5 & 2.0 & $\mathrm{Cs} 2 \mathrm{CO} 3(4)$ & DMSO & 75 \\
\hline 6 & 2.0 & $\mathrm{Cs} 2 \mathrm{CO} 3(4)$ & THF & 10 \\
\hline 7 & 2.0 & $\mathrm{Cs} 2 \mathrm{CO} 3(4)$ & Dioxane & 14 \\
\hline 8 & 2.0 & $\mathrm{Cs} 2 \mathrm{CO} 3(4)$ & DMF & 21 \\
\hline 9 & 1.0 & $\mathrm{Cs} 2 \mathrm{CO} 3(4)$ & DMSO & 59 \\
\hline 10 & 1.5 & $\mathrm{Cs} 2 \mathrm{CO} 3(4)$ & DMSO & 68 \\
\hline 11 & 2.0 & $\mathrm{Cs} 2 \mathrm{CO} 3(2.5)$ & DMSO & 73 \\
\hline 12 & 2.0 & $\mathrm{Cs} 2 \mathrm{CO} 3(1.0)$ & DMSO & 33 \\
\hline 13 & 2.0 & $\mathrm{Cs} 2 \mathrm{CO} 3(0.5)$ & DMSO & 19 \\
\hline 14 & 2.0 & - & DMSO & 0 \\
\hline
\end{tabular}

\footnotetext{
${ }^{a}$ The reactions were carried out using $1 \mathbf{a}(1.0 \mathrm{mmol}), \mathbf{2 a}(1.0 \sim 2.0$ equiv), and base in $4.0 \mathrm{~mL}$ of solvent in a sealed tube at $100{ }^{\circ} \mathrm{C}$ for $24 \mathrm{~h} .{ }^{b}$ yields of 3aa are isolated yields.
}

With the optimized conditions established (Table 1, entry 11), we then investigated the scope and generality of the imidazole formation with the use of various alkynes bearing electron-donating and electron-withdrawing groups, as well as several amidoximes, and the obtained results are concluded in Scheme 2. The reactions of 1a with various aromatic terminal alkynes bearing electron-donating groups and electron-withdrawing groups could occur smoothly, to give the corresponding imidazoles in moderate to good yields. It was noted that para-alkyl-substituted aromatic alkynes ( $\mathrm{R}^{\prime \prime}=\mathrm{Me}, \mathbf{2 b}$; Et, 2c; $n$-Pr, 2d; $n$-Bu, 2e; t-Bu, 2f; 4' -n-pentylcyclohexyl, 2g) showed high reactivity to produce the desired products (3ab $\sim 3 \mathbf{a g}$ ) in 69-84\% yields. para-Phenyl phenyl acetylene (2h) reacted with 1a afforded 3ah 
in a high yield (81\%). The reaction of para-chlorophenyl acetylene (2i), an electron-poor alkyne, with $\mathbf{1 a}$ gave the product 3 ai in a moderate yield (68\%). In addition, the reaction of 1a with para-bromophenyl acetylene (2j) afford $3 \mathbf{a j}$ in a 59\% yield. These results were apparent that the electron-donating group on aromatic terminal alkynes would benefit the formation of imidazoles.

When meta-substituted aromatic terminal alkynes were used, the reactions gave slight decrease in yields as compared to para-substituted ones. For example, the reactions of 1a with (3-methylphenyl)ethyne (2k), or with (3-chlorophenyl)ethyne (21) gave 3ak in a 63\% yield (vs. 3ab $75 \%$ ) and $3 a 1$ in a $54 \%$ yield (vs. 3ag $68 \%$ ), respectively. It was noted that, in these cases, alkyne bearing electron-donating group also show relatively high reactivity (3ak vs. 3al), similar to the results as $\mathrm{R}^{\prime \prime}$ at para-position.

In addition, the present reaction conditions are also suitable for the annulation of 1a with 2-naphthylacetylene (2m), and with 2-thienylacetylene (2n), a heteroaromatic terminal alkyne, afforded 3 am and 3 an in 55\% and 56\% yields, respectively.

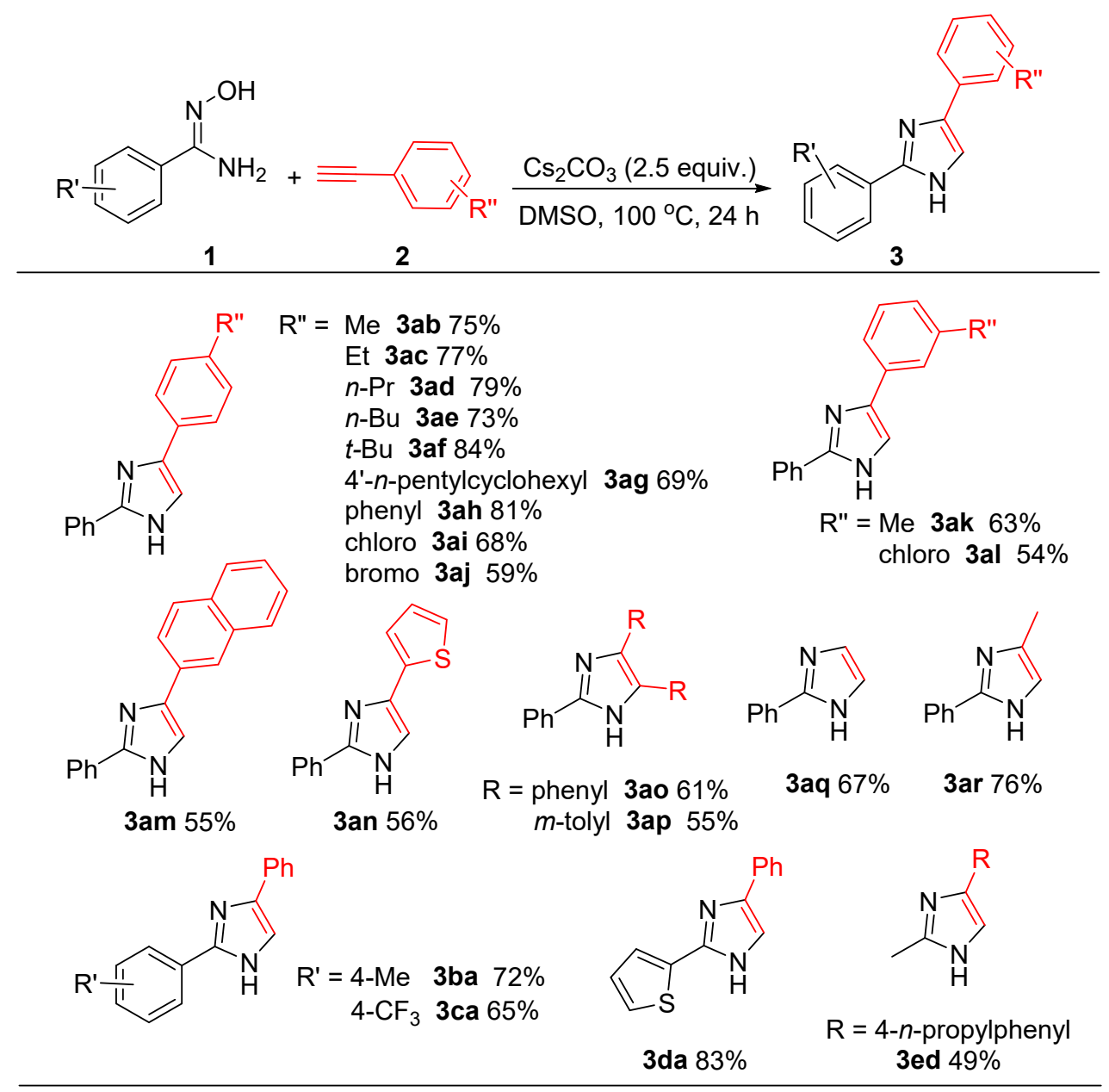

${ }^{a}$ Reactions were carried out using 1 (1.0 mmol), 2 (2.0 mmol), and $\mathrm{Cs}_{2} \mathrm{CO}_{3}(2.5 \mathrm{mmol})$ in $4.0 \mathrm{~mL}$ of DMSO in a sealed tube at $100{ }^{\circ} \mathrm{C}$ for $24 \mathrm{~h}$.

Scheme 2. Substrate scope of imidazole synthesis ${ }^{a}$.

Moreover, under the similar conditions, internal alkynes can also undergo the cyclocondensation with 1a to produce the corresponding 2,4,5-trisubstituted imidazoles. For instance, the reactions of 1a with 1,2-diphenyacetylene (2o), or with 1,2-bis(m-tolyl)acetylene (2p) gave 3ao and 3ap in 61\% and $55 \%$ yields. 
Interestingly, when 1-(trimethylsilyl)acetylene (2q) and 1-methyl-2-trimethylsilylacetylene (2r) were employed, the reactions with 1a produced 2-phenylimidazole (3aq, 67\%) and 2-phenyl-4methylimidazole (3ar, 76\%), indicating that desilylation took place smoothly under the used basic conditions.

On the other hand, the substituent $\left(R^{\prime}\right)$ effect on the aryl group of $\mathbf{1}$ was also investigated, and the results from two representative examples with the use of either electron-donating group (para-Me, 1b) or electron-withdrawing group (para- $\left.\mathrm{CF}_{3}, \mathbf{1 c}\right)$ were reported. As shown in Scheme 2, the corresponding products of $3 \mathbf{b a}$ and $3 \mathbf{c a}$ could be obtained in $72 \%$ and $65 \%$ yields, respectively. Again, the electron-donating group is favorable for the formation of imidazole ring.

Additionally, the present reaction conditions could be applied to heteroarylamidoximes and alkylamidoximes. For example, the reaction between 2-thienylamidoxime (1d) and $\mathbf{2 a}$ afford $3 \mathbf{d a}$ in a $83 \%$ yield, and the reaction of acetamidoxime (1e) with $2 \mathrm{~d}$ produced the expected product of $3 \mathbf{e d}$ in a $49 \%$ yield.

It is worth noting that the present reaction conditions are tolerant to $\mathrm{C}\left(s p^{2}\right)-\mathrm{Cl}$ and $\mathrm{C}\left(s p^{2}\right)$ - $\mathrm{Br}$ bonds, the obtained products bearing $\mathrm{C}\left(s p^{2}\right)-X$ bonds have a highly potential application in organic synthesis via their cross-coupling reactions.

Amidoximes have been well known to be the useful building blocks for the construction of nitrogen-heterocyclic compounds, and the five-membered nitrogen-heterocyclic compounds formation is usually proposed to involve the step of $\mathrm{N}-\mathrm{O}$ bond cleavage via 3,3-sigmatropic rearrangement [37-39]. Therefore, on the basis of our results and the known chemistry of amidoximes, a possible reaction mechanism for the formation of imidazole ring is shown in Scheme 3. It involves the regioselective nucleophilic addition of $\mathrm{O}-\mathrm{H}$ bond to alkyne under basic conditions, giving an $o$-vinylated amidoxime (4), which undergoes sequential 3,3-sigmatropic rearrangement forming intermediate 5 , and intramolecular nucleophilic addition of nitrogen atom to aldehyde affording five-membered heterocyclic intermediate $\mathbf{6}$, followed by dehydration to form imidazole ring.
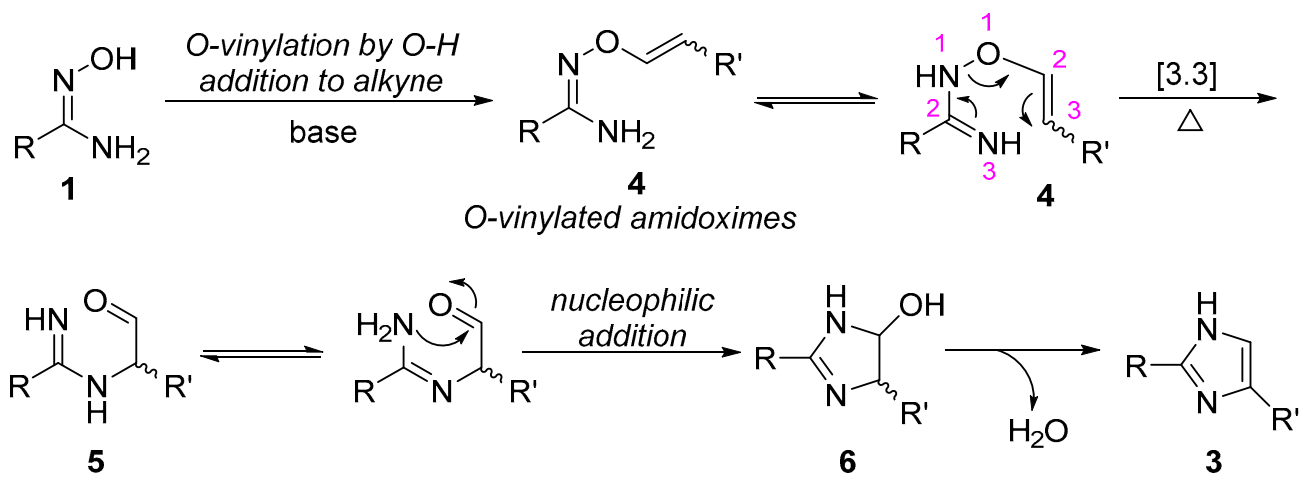

Scheme 3. Proposed mechanism for the formation of imidazoles.

In order to support the proposed mechanism, a theoretical calculation was conducted by using the quantum chemistry program Gaussian 16 [40], and all structures were optimized by using M06-2X Minnesota functional with the 6-31G $(\mathrm{d}, \mathrm{p})$ basis set [41]. Figure 2 shows the free energy changes in the base-promoted annulation of 1a with 2a forming 3aa with the transition states for the formation of key intermediates 4-6. It clearly indicates that the transition state for the formation of intermediates 4 (from TS1) and 6 (from TS3) can be found with low activation energies. The key step for the formation of imidazole ring is the 3,3-sigmatropic rearrangement to give intermediate 5 . The transition state (TS2) between R4 (intermediate 4) and R5 (intermediate 5) is not very high in activation energy, with $30.8 \mathrm{kcal} / \mathrm{mol}$ (TS2-R4), and the Gibbs free energy change in this step is $-43.2 \mathrm{kcal} / \mathrm{mol}$. These results have confirmed that at $100{ }^{\circ} \mathrm{C}(373.15 \mathrm{~K}$, reaction temperature), 3,3-sigmatropic rearrangement can occur smoothly to construct imidazole ring as the proposed routes shown in Scheme 3. 


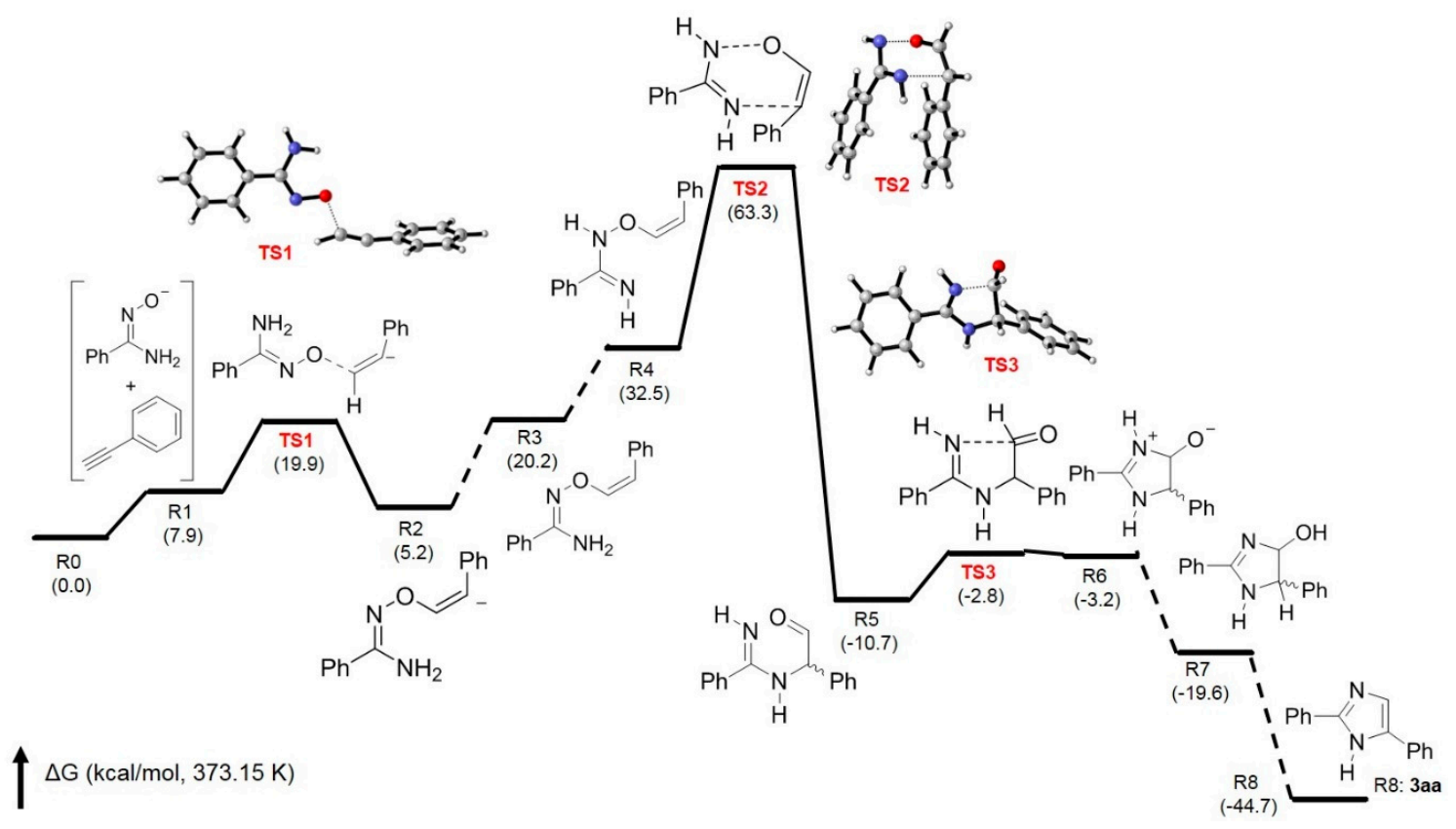

Figure 2. Free energy profile for the base-promoted annulation of 1a with 2a affording 3aa.

\section{Materials and Methods}

\subsection{General Methods}

All commercial reagents are analytically pure and used directly without further purification. Nuclear magnetic resonance (NMR) spectra were recorded on an ECA-400 spectrometer (JEOL, Tokyo, Japan) using DMSO- $d_{6}$ as solvent at $298 \mathrm{~K} .{ }^{1} \mathrm{H}-\mathrm{NMR}(400 \mathrm{MHz})$ chemical shifts $(\delta)$ were referenced to internal standard TMS (for $1 \mathrm{H}, \delta=0.00 \mathrm{ppm}) .{ }^{13} \mathrm{C}-\mathrm{NMR}(100 \mathrm{MHz})$ chemical shifts were referenced to internal solvent DMSO- $d_{6}$ (for ${ }^{13} \mathrm{C}, \delta=39.52 \mathrm{ppm}$ ). Mass spectra (MS) were obtained on a GC-MS-QP2010S (Shimadzu, Tokyo, Japan), and the high-resolution mass spectra (HRMS) with electron spray ionization (ESI) were obtained with a micrOTOF-Q spectrometer (Agilent, California, CA, USA). Single crystals of 3aa were obtained by slow evaporation of their solution in a mixture solvents of petroleum, ethyl acetate and $\mathrm{EtOH}$.

\subsection{Typical Experimental Procedure for the Synthesis of 2,4-Diphenyl-1H-imidazole (3aa)}

A mixture of benzamidoxime (1a, $136.1 \mathrm{mg}, 1.0 \mathrm{mmol})$, phenylacetylene $(2 \mathrm{a}, 204.1 \mathrm{mg}, 2.0 \mathrm{mmol})$ and $\mathrm{Cs}_{2} \mathrm{CO}_{3}(815.1 \mathrm{mg}, 2.5 \mathrm{mmol})$ in DMSO $(4.0 \mathrm{~mL})$, in a $25 \mathrm{~mL}$ screw-capped thick-walled Pyrex tube was stirred at $100{ }^{\circ} \mathrm{C}$ for $24 \mathrm{~h}$ in an oil bath. After the reaction mixture was cooled to room temperature, it was poured into a solvent mixture of water $(50.0 \mathrm{~mL})$ and ethyl acetate $(20.0 \mathrm{~mL})$, and the two phases were then separated. The aqueous layer was extracted with ethyl acetate $(3 \times 20.0 \mathrm{~mL})$. The combined organic extracts were dried over anhydrous $\mathrm{Na}_{2} \mathrm{SO}_{4}$. After removal of the solvent under reduced pressure, the residue was purified by column chromatography on silica gel with petroleum ether/ethyl acetate (gradient mixture ratio from 100:0 to 70:20) as eluent, to afford 3aa as a white solid (160.4 mg, $73 \%)$.

The characterization data for known products of 3aa, 3ab, 3af, 3ah-3al, 3an, 3ao, 3aq, 3ar, 3ba, 3ca and 3da reported in the Supplementary Materials. Each of 3ac, 3ad, 3ae, 3ag, 3am, 3ap and 3ed are new compounds, and their spectroscopic data are reported below. 


\subsection{Characterization Data of Products}

4-(4-Ethylphenyl)-2-phenyl-1H-imidazole (3ac):

White solid (190.4 mg, 77\%). ${ }^{1} \mathrm{H}-\mathrm{NMR}\left(400 \mathrm{MHz}, \mathrm{DMSO}-d_{6}\right) \delta 12.71(\mathrm{~s}, 1 \mathrm{H}), 8.17(\mathrm{~d}, J=7.6 \mathrm{~Hz}, 2 \mathrm{H})$, $7.87(\mathrm{~d}, J=7.6 \mathrm{~Hz}, 2 \mathrm{H}), 7.70(\mathrm{~s}, 1 \mathrm{H}), 7.50(\mathrm{t}, J=7.6 \mathrm{~Hz}, 2 \mathrm{H}), 7.37(\mathrm{t}, J=7.3 \mathrm{~Hz}, 1 \mathrm{H}), 7.25(\mathrm{~d}, J=8.0 \mathrm{~Hz}$, $2 \mathrm{H}), 2.61(\mathrm{q}, J=7.5 \mathrm{~Hz}, 2 \mathrm{H}), 1.20(\mathrm{t}, J=7.5 \mathrm{~Hz}, 3 \mathrm{H}) ;{ }^{13} \mathrm{C}-\mathrm{NMR}\left(100 \mathrm{MHz}\right.$, DMSO- $\left.d_{6}\right) \delta 146.1,141.9,130.8$, $128.7,128.0,127.9,125.0,124.5,28.0,15.6$ HRMS (ESI) $m / z:[\mathrm{M}+\mathrm{H}]^{+}$calcd for $\mathrm{C}_{17} \mathrm{H}_{16} \mathrm{~N}_{2}, 249.1386$; found 249.1388 .

2-Phenyl-4-(4-n-propylphenyl)-1H-imidazole (3ad):

White solid (206.7 mg, 79\%). ${ }^{1} \mathrm{H}-\mathrm{NMR}\left(400 \mathrm{MHz}\right.$, DMSO- $\left.d_{6}\right) \delta 12.64(\mathrm{sbr}, 1 \mathrm{H}), 8.15(\mathrm{~d}, J=7.7 \mathrm{~Hz}, 2 \mathrm{H})$, $7.85(\mathrm{~d}, J=7.7 \mathrm{~Hz}, 2 \mathrm{H}), 7.66(\mathrm{~s}, 1 \mathrm{H}), 7.49(\mathrm{t}, J=7.5 \mathrm{~Hz}, 2 \mathrm{H}), 7.38(\mathrm{t}, J=7.3 \mathrm{~Hz}, 1 \mathrm{H}), 7.22(\mathrm{~d}, J=7.8 \mathrm{~Hz}$, $2 \mathrm{H}), 2.56(\mathrm{t}, J=7.4 \mathrm{~Hz}, 2 \mathrm{H}), 1.69-1.53(\mathrm{~m}, 2 \mathrm{H}), 0.91(\mathrm{t}, J=7.4 \mathrm{~Hz}, 3 \mathrm{H}) ;{ }^{13} \mathrm{C}-\mathrm{NMR}\left(100 \mathrm{MHz}\right.$, DMSO- $\left.d_{6}\right) \delta$ $146.0,140.2,130.8,129.3,128.5,128.4,127.9,125.0,124.4,118.7,115.3,37.0,24.0,13.5$; HRMS (ESI) $m / z$ : $[\mathrm{M}+\mathrm{H}]^{+}$calcd for $\mathrm{C}_{18} \mathrm{H}_{18} \mathrm{~N}_{2}$, 263.1543; found 263.1540.

4-(4-Butylphenyl)-2-phenyl-1H-imidazole (3ae):

White solid (201.3 mg, 73\%). ${ }^{1} \mathrm{H}$ NMR (400 MHz, DMSO- $\left.d_{6}\right) \delta 12.64(\mathrm{sbr}, 1 \mathrm{H}), 8.14(\mathrm{~d}, J=7.4 \mathrm{~Hz}, 2 \mathrm{H})$, $7.83(\mathrm{~d}, J=7.3 \mathrm{~Hz}, 2 \mathrm{H}), 7.65(\mathrm{~s}, 1 \mathrm{H}), 7.48(\mathrm{t}, J=7.2 \mathrm{~Hz}, 2 \mathrm{H}), 7.36(\mathrm{t}, J=7.0 \mathrm{~Hz}, 1 \mathrm{H}), 7.21(\mathrm{~d}, J=7.5 \mathrm{~Hz}$, $2 \mathrm{H}), 2.58(\mathrm{t}, J=7.3 \mathrm{~Hz}, 2 \mathrm{H}), 1.63-1.50(\mathrm{~m}, 2 \mathrm{H}), 1.40-1.22(\mathrm{~m}, 2 \mathrm{H}), 0.90(\mathrm{t}, J=7.1 \mathrm{~Hz}, 3 \mathrm{H}) ;{ }^{13} \mathrm{C}-\mathrm{NMR}$ $\left(100 \mathrm{MHz}, \mathrm{DMSO}-d_{6}\right) \delta 146.0,140.3,130.8,129.3,128.5,128.3,127.8,124.9,124.4,34.6,33.1,21.7,13.7$; HRMS (ESI) $m / z:[\mathrm{M}+\mathrm{H}]^{+}$calcd for $\mathrm{C}_{19} \mathrm{H}_{20} \mathrm{~N}_{2}, 277.1699$; found 277.1698.

4-(4-(4-n-Pentylcyclohexyl)phenyl)-2-phenyl-1H-imidazole (3ag):

White Solid (256.7 mg, 69\%). ${ }^{1} \mathrm{H}-\mathrm{NMR}\left(400 \mathrm{MHz}, \mathrm{DMSO}-d_{6}\right) \delta 12.58(\mathrm{~s}, 1 \mathrm{H}), 8.00(\mathrm{~d}, J=7.6 \mathrm{~Hz}, 2 \mathrm{H})$, $7.74(\mathrm{~d}, J=7.8 \mathrm{~Hz}, 2 \mathrm{H}), 7.63(\mathrm{~s}, 1 \mathrm{H}), 7.46(\mathrm{t}, J=7.6 \mathrm{~Hz}, 2 \mathrm{H}), 7.35(\mathrm{t}, J=7.3 \mathrm{~Hz}, 1 \mathrm{H}), 7.22(\mathrm{~d}, J=8.0 \mathrm{~Hz}$, $2 \mathrm{H}), 2.50-2.38(\mathrm{~m}, 1 \mathrm{H}), 1.83-1.80(\mathrm{~m}, 4 \mathrm{H}), 1.52-1.37(\mathrm{~m}, 2 \mathrm{H}), 1.35-1.13(\mathrm{~m}, 10 \mathrm{H}), 1.10-0.95(\mathrm{~m}, 2 \mathrm{H}), 0.88$ $(\mathrm{t}, J=6.6 \mathrm{~Hz}, 3 \mathrm{H}) ;{ }^{13} \mathrm{C}-\mathrm{NMR}\left(100 \mathrm{MHz}, \mathrm{DMSO}-d_{6}\right) \delta 145.8,145.4,130.6,128.6,128.0,126.7,124.8,124.3$, 43.9, 36.8, 36.6, 33.8, 33.1, 31.6, 26.0, 22.1, 13.9; HRMS (ESI) $m / z:[\mathrm{M}+\mathrm{H}]^{+}$calcd for $\mathrm{C}_{26} \mathrm{H}_{32} \mathrm{~N}_{2}, 373.2638$; found 373.2635 .

4-(Naphthalen-2-yl)-2-phenyl-1H-imidazole (3am):

White solid (148.3 mg, 55\%). ${ }^{1} \mathrm{H}-\mathrm{NMR}\left(400 \mathrm{MHz}\right.$, DMSO- $\left.d_{6}\right) \delta 12.72(\mathrm{~s}, 1 \mathrm{H}), 8.39(\mathrm{~s}, 1 \mathrm{H}), 8.09-7.85(\mathrm{~m}$, 7H), 7.55-7.34 (m, 5H); ${ }^{13} \mathrm{C}-\mathrm{NMR}\left(100 \mathrm{MHz}\right.$, DMSO- $\left.d_{6}\right) \delta 146.0,140.9,133.3,132.1,131.8,130.5,128.6$, 128.1, 127.7, 127.6, 127.4, 126.1, 125.1, 125.0, 124.9, 123.7, 121.7, 114.9; HRMS (ESI) $m / z:[\mathrm{M}+\mathrm{H}]^{+}$calcd for $\mathrm{C}_{19} \mathrm{H}_{14} \mathrm{~N}_{2}$, 271.1230; found 271.1235.

2-Phenyl-4,5-di-m-tolyl-1H-imidazole (3ap):

White solid (178.1 mg, 55\%). ${ }^{1} \mathrm{H}-\mathrm{NMR}\left(400 \mathrm{MHz}\right.$, DMSO- $\left.d_{6}\right) \delta 12.59(\mathrm{~s}, 1 \mathrm{H}), 8.08(\mathrm{~d}, J=8.3 \mathrm{~Hz}, 3 \mathrm{H})$, 7.50-7.43 (m, 3H), 7.40-7.24 (m, 5H), 7.22-7.12 (m, 2H), $7.04(\mathrm{~d}, J=6.9 \mathrm{~Hz}, 1 \mathrm{H}), 2.34(\mathrm{~s}, 3 \mathrm{H}), 2.27(\mathrm{~s}$, $3 \mathrm{H}) ;{ }^{13} \mathrm{C}-\mathrm{NMR}\left(100 \mathrm{MHz}\right.$, DMSO-d $\left.d_{6}\right) \delta 145.2,137.6,137.0,135.0,130.9,130.3,129.5,128.8,128.5,128.3$, $128.2,128.1,128.0,127.8,127.6,127.0,125.5,125.1,124.1,21.0,20.9$; HRMS (ESI) $m / z:[\mathrm{M}+\mathrm{H}]^{+}$calcd for $\mathrm{C}_{23} \mathrm{H}_{20} \mathrm{~N}_{2}, 325.1699$; found 325.1697 .

2-Methyl-4-(4-n-propylphenyl)-1H-imidazole (3ed):

Waxy oil (98.1 mg, 49\%). ${ }^{1} \mathrm{H}-\mathrm{NMR}\left(400 \mathrm{MHz}, \mathrm{DMSO}-d_{6}\right) \delta 7.55(\mathrm{~d}, J=8.1 \mathrm{~Hz}, 2 \mathrm{H}), 7.28(\mathrm{~s}, 1 \mathrm{H})$, $7.09(\mathrm{~d}, J=8.2 \mathrm{~Hz}, 2 \mathrm{H}), 2.50-2.41(\mathrm{~m}, 2 \mathrm{H}), 2.26(\mathrm{~s}, 3 \mathrm{H}), 1.60-1.46(\mathrm{~m}, 2 \mathrm{H}), 0.85(\mathrm{t}, J=7.3 \mathrm{~Hz}, 3 \mathrm{H})$; ${ }^{13} \mathrm{C}-\mathrm{NMR}\left(100 \mathrm{MHz}\right.$, DMSO- $\left.d_{6}\right) \delta 144.1,1,139.5,131.5,128.4,123.9,36.9,24.0,13.9,13.6$; HRMS (ESI) $m / z:[\mathrm{M}+\mathrm{H}]^{+}$calcd for $\mathrm{C}_{13} \mathrm{H}_{16} \mathrm{~N}_{2}, 201.0681$; found 201.0687 


\section{Conclusions}

In summary, we developed a simple and efficient method to prepare 2,4-disubstituted imidazoles in moderate to good yields from easily available starting materials of amidoximes and terminal alkynes promoted by $\mathrm{Cs}_{2} \mathrm{CO}_{3}$ in DMSO. The significant advantages of the present procedure include the formation of imidazoles under transition-metal-free and ligand-free conditions, high atom-utilization, and a broad substrate scope. 2-substituted and 2,4,5-trisubstituted imidazoles could be also prepared under the similar conditions by using 1-(trimethylsilyl)acetylene and internal alkynes.

Supplementary Materials: The following are available online. The characterization data of the known products, copies of ${ }^{1} \mathrm{H}$ - and ${ }^{13} \mathrm{C}-\mathrm{NMR}$ charts of all products, X-ray structural details (including CIF files) of $3 \mathbf{a a}$, and computational predicted energies and cartesian coordinates.

Author Contributions: Investigation, writing—original draft preparation, H.M.; investigation, M.A.I. \& L.L.; conceptualization, supervision, writing-review and editing, R.H. All authors have read and agreed to the published version of the manuscript.

Funding: This research was funded by National Natural Science Foundation of China (21673124). Hina Mehmood and Muhammad Asif Iqbal thank the China Scholarship Council (CSC) for generous support for their study in Tsinghua University as $\mathrm{PhD}$ candidates.

Acknowledgments: We thank Tsinghua Xuetang Talents Program for computational hardware and software support.

Conflicts of Interest: The authors declare no conflict of interest.

\section{References and Notes}

1. Ward, K.E.; Hume, A.L. Olmesartan (Benicar) for hypertension. Am. Fam. Physician 2005, 72, 673-674.

2. Ianiro, G.; Bibbo, S.; Montalto, M.; Ricci, R.; Gasbarrini, A.; Cammarota, G. Systematic review: Sprue-like enteropathy associated with olmesartan. Aliment. Pharmacol. Ther. 2014, 40, 16-23. [CrossRef] [PubMed]

3. Choi, E.Y.K.; McKenna, B.J. Olmesartan-associated enteropathy: A review of clinical and histologic findings. Arch. Pathol. Lab. Med. 2015, 139, 1242-1247. [CrossRef] [PubMed]

4. Redon, J.; Weber, M.A.; Reimitz, P.-E.; Wang, J.-G. Comparative effectiveness of an angiotensin receptor blocker, olmesartan medoxomil, in older hypertensive patients. J. Clin. Hypertens. 2018, 20, 356-365. [CrossRef] [PubMed]

5. McIntyre, M.; Caffe, S.E.; Michalak, R.A.; Reid, J.L. Losartan, an orally active angiotensin (AT1) receptor antagonist: A review of its efficacy and safety in essential hypertension. Pharmacol. Ther. 1997, 74, 181-194. [CrossRef]

6. Conlin, P.R. Efficacy and safety of angiotensin receptor blockers: A review of Losartan in essential hypertension. Curr. Ther. Res. 2001, 62, 79-91. [CrossRef]

7. Rubio-Guerra, A.F.; Garro-Almendaro, A.K.; Elizalde-Barrera, C.I.; Suarez-Cuenca, J.A.; Duran-Salgado, M.B. Effect of losartan combined with amlodipine or with a thiazide on uric acid levels in hypertensive patients. Ther. Adv. Cardiovasc. Dis. 2017, 11, 57-62. [CrossRef]

8. Oxford, A.W.; Bell, J.A.; Kilpatrick, G.J.; Ireland, S.J.; Tyers, M.B. Ondansetron and related 5-HT, antagonists: Recent advances. Prog. Med. Chem. 1992, 29, 239-270.

9. Del Favero, A.; Roila, F.; Tonato, M. Reducing chemotherapy-induced nausea and vomiting. Current perspectives and future possibilities. Drug Saf. 1993, 9, 410-428. [CrossRef]

10. Christofaki, M.; Papaioannou, A. Ondansetron: A review of pharmacokinetics and clinical experience in postoperative nausea and vomiting. Expert. Opin. Drug Metab. Toxicol. 2014, 10, 437-444. [CrossRef]

11. Dewinter, G.; Staelens, W.; Veef, E.; Teunkens, A.; Van de Velde, M.; Rex, S. Simplified algorithm for the prevention of postoperative nausea and vomiting: A before-and-after study. Br. J. Anaesth. 2018, 120, 156-163. [CrossRef] [PubMed]

12. Baumann, M.; Baxendale, I.R.; Ley, S.V.; Nikbin, N. An overview of the key routes to the best selling 5-membered ring heterocyclic pharmaceuticals. Beilstein J. Org. Chem. 2011, 7, 442-495. [CrossRef] [PubMed]

13. Rani, N.; Sharma, A.; Singh, R. Imidazoles as promising scaffolds for antibacterial activity: A review. Mini Rev. Med. Chem. 2013, 13, 1812-1835.

14. Zhang, L.; Peng, X.-M.; Damu, G.L.V.; Geng, R.-X.; Cheng-He Zhou, C.-H. Comprehensive review in current developments of imidazole-based medicinal chemistry. Med. Res. Rev. 2014, 34, 340-437. [CrossRef] 
15. Ali, I.; Lonea, M.N.; Aboul-Enein, H.Y. Imidazoles as potential anticancer agents. Med. Chem. Commun. 2017, 8, 1742-1773. [CrossRef] [PubMed]

16. Bauman, J.E., Jr.; Wang, J.C. Imidazole complexes of Nickel (II), Copper (II), Zinc (II) and Silver (I). Inorg. Chem. 1963, 3, 368-373. [CrossRef]

17. Gómez, E.; Huertos, W.A.; Pérez, J.; Riera, L.; Menéndez-Velázquez, A. Organometallic complexes with terminal imidazolato ligands and their use as metalloligands. Inorg. Chem. 2010, 49, 9527-9534. [CrossRef]

18. Kamijo, S.; Yamamoto, Y. Recent progress in the catalytic synthesis of imidazoles. Chem. Asian J. 2007, 2 , 568-578. [CrossRef]

19. Bellina, F.; Cauteruccio, S.; Rossi, R. Synthesis and biological activity of vicinal diaryl-substituted 1H-imidazoles. Tetrahedron 2007, 63, 4571-4624. [CrossRef]

20. Daraji, D.G.; Prajapati, N.P.; Patel, H.D. Synthesis and applications of 2-substituted imidazole and its derivatives: A review. J. Heterocycl. Chem. 2019, 56, 2299-2317. [CrossRef]

21. Chen, C.-Y.; Hu, W.-P.; Yan, P.-C.; Senadi, G.C.; Wang, J.-J. Metal-free, acid-promoted synthesis of imidazole derivatives via a multicomponent reaction. Org. Lett. 2013, 15, 6116-6119. [CrossRef] [PubMed]

22. Lee, C.F.; Holownia, A.; Bennett, J.M.; Elkins, J.M.; St. Denis, J.D.; Adachi, S.; Yudin, A.K. Oxalyl boronates enable modular synthesis of bioactive imidazoles. Angew. Chem. Int. Ed. 2017, 56, 6264-6267. [CrossRef] [PubMed]

23. Dubovtsev, A.Y.; Dar'in, D.V.; Krasavin, M.; Kukushkin, V.Y. Gold-catalyzed oxidation of internal alkynes into benzils and its application for one-pot synthesis of five-, six- and seven-membered azaheterocycles. Eur. J. Org. Chem. 2019, 1856-1864. [CrossRef]

24. Naidoo, S.; Jeena, V. One-pot, two-step metal and acid-free synthesis of trisubstituted imidazole derivatives via oxidation of internal alkynes using an iodine/DMSO system. Eur. J. Org. Chem. 2019, 1107-1113. [CrossRef]

25. Li, J.; Neuville, L. Copper-catalyzed oxidative deamination of terminal alkynes by amidines: Synthesis of 1,2,4-trisubstituted imidazoles. Org. Lett. 2013, 15, 1752-1755. [CrossRef] [PubMed]

26. Chen, X.Y.; Englert, U.; Bolm, C. Base-mediated syntheses of di- and trisubstituted imidazoles from amidine hydrochlorides and bromoacetylenes. Chem. Eur. J. 2015, 21, 13221-13224. [CrossRef]

27. Su, J.; Chen, Q.; Lu, L.; Ma, Y.; Auyoung, G.H.L.; Hua, R. Base-promoted nucleophilic fluoroarenes substitution of C-F bonds. Tetrahedron 2018, 74, 303-307. [CrossRef]

28. Iqbal, M.A.; Lu, L.; Mehmood, H.; Khan, D.M.; Hua, R. Quinazolinone synthesis through base-promoted SNAr reaction of ortho-fluorobenzamides with amides followed by cyclization. ACS Omega 2019, 4, 8207-8213. [CrossRef]

29. Iqbal, M.A.; Mehmood, H.; Lv, J.; Hua, R. Base-promoted SNAr reactions of fluoro- and chloroarenes as a route to $N$-aryl indoles and carbazoles. Molecules 2019, 24, 1145. [CrossRef]

30. Chen, Q.; Wang, Y.; Hua, R. Base-promoted chemodivergent formation of 1,4-benzoxazepin-5(4H)-ones and 1,3-benzoxazin-4(4H)-ones switched by solvents. Molecules 2019, 24, 3773. [CrossRef]

31. Nizami, T.A.; Hua, R. Cycloaddition of 1,3-butadiynes: Efficient synthesis of carbo- and heterocycles. Molecules 2014, 19, 13788-13802. [CrossRef] [PubMed]

32. Hua, R.; Nizami, T.A. Synthesis of heterocycles by using propargyl compounds as versatile synthons. Mini-Rev. Org. Chem. 2018, 15, 198-207. [CrossRef]

33. Zheng, L.; Hua, R. C-H activation and alkyne annulation via automatic or intrinsic directing groups: Towards high step economy. Chem. Rec. 2018, 18, 556-569. [CrossRef] [PubMed]

34. Khan, D.M.; Hua, R. Isoquinolone synthesis via Zn (OTf $)_{2}$-catalyzed aerobic cyclocondensation of 2-(1-alkynyl) benzaldehydes with arylamines. Catalysts 2020, 10, 683. [CrossRef]

35. One similar structural substrate reaction between ethyl amino-oximinoacetate (in 1, $\mathrm{R}=\mathrm{COOEt}$ ) and methyl propiolate (an active alkyne) in the presence of $\mathrm{Et}_{3} \mathrm{~N}$ under reflux xylene giving 2-carbethoxy-4-carbomethoxyimidazole in 70\% yield was reported, see: Branco, P.S.; Prabhakar, S.; Lobo, A.M.; Wiliams, D.J. Reactions of hydroxylamines with ethyl cyanoformate. Preparation of aminonitrones and their synthetic applications. Tetrahedron 1992, 48, 6335-6360. Very recently, a microwave-assisted synthesis of imidazoles via nucleophilic catalysis has been reported by the addition of amidoximes to activated alkynes followed by a thermally induced rearrangement of the in situ generated $O$-vinylamidoxime intermediates, see: Shabalin, D.A.; Dunsford, J.J.; Ngwerume, S.; Saunders, A.R.; Gill, D.M.; Camp, J.E. Synthesis of 2,4-disubstituted imidazoles via nucleophilic catalysis. Synlett 2020, 31, 797-800. 
36. The structure of 3aa was further confirmed by its x-ray diffraction studies (CCDC2012403), and the x-ray structural details are reported in Supplementary Materials.

37. Tabolin, A.A.; Ioffe, S.L. Rearrangement of N-oxyenamines and related reactions. Chem. Rev. 2014, 114, 5426-5476. [CrossRef]

38. Bolotin, D.S.; Bokach, N.A.; Demakova, M.Y.; Kukushkin, V.Y. Metal-involving synthesis and reactions of oximes. Chem. Rev. 2017, 117, 13039-13122. [CrossRef]

39. Sridhar Madabhushi, S.; Vangipuram, V.S.; Mallu, K.K.R.; Chinthala, N.; Beeram, C.R. Europium (III) triflate-catalyzed trofimov synthesis of polyfunctionalized pyrroles. Adv. Synth. Catal. 2012, 354, 1413-1416. [CrossRef]

40. Frisch, M.J.; Trucks, G.W.; Schlegel, H.B.; Scuseria, G.E.; Robb, M.A.; Cheeseman, J.R.; Scalmani, G.; Barone, V.; Petersson, G.A.; Nakatsuji, H.; et al. Gaussian 16, Revision B.01; Gaussian, Inc.: Wallingford, CT, USA, 2016.

41. Zhao, Y.; Truhlar, D.G. The M06 suite of density functionals for main group thermochemistry, thermochemical kinetics, noncovalent interactions, excited states, and transition elements: Two new functionals and systematic testing of four M06-class functionals and 12 other functionals. Theor. Chem. Acc. 2008, 120, 215-241. [CrossRef]

Sample Availability: Samples of the products are not available from the authors. 